\title{
CONSTITUTIONAL RIGHTS AND THE POSSIBILITY OF DETACHED CONSTRUCTIVE INTERPRETATION*
}

\author{
DERECHOS CONSTITUCIONALES Y LA POSIBILIDAD \\ DE UNA INTERPRETACIÓN CONSTRUCTIVA DISTANCIADA
}

Wil WALUCHOW**

\section{Resumen:}

En este artículo defiendo a la revisión constitucional frente a la acusación de que ésta está necesariamente reñida con el principio democrático. Para ello, he recurrido tanto a la teoría dworkiniana de la interpretación constructiva como a la teoría raziana de los enunciados y del razonamiento desde un punto de vista normativamente distanciado. Después de argumentar que la interpretación constructiva puede ser realizada desde un punto de vista distinto al del intérprete, me dispongo a defender las siguientes tesis: (1) La interpretación y la revisión constitucional pueden ser realizadas desde el punto de vista de la comunidad democrática y su moral constitucional; (2) Este proceso puede ser emprendido por un juez sin involucrar deliberadamente sus propias convicciones morales; (3) Cuando se realiza desde este punto de vista, la interpretación y la revisión constitucional pueden ser efectuadas consistentemente con la democracia; y (4) Esto es así aun cuando tales actividades requieran, en buena medida, de un razonamiento y argumentación moral sustantiva de parte de los jueces.

* Artículo recibido el 14 de noviembre de 2014 y aceptado para su publicación el 30 de noviembre de 2014.

** Senator William McMaster Chair of Constitutional Studies. Department of Philosophy. McMaster University. Hamilton, ON, Canada. 
Este libro forma parte del acervo de la Biblioteca Jurídica Virtual del Instituto de Investigaciones Jurídicas de la UNAM

WIL WALUCHOW

Palabras clave:

Interpretación constitucional, revisión judicial, moral constitucional de la comunidad, razonamiento moral, moral política, legitimidad democrática.

\begin{abstract}
:
In this paper I defend constitutional review against the charge that it necessarily runs afoul of democratic principle. In so doing, I draw both on Dworkin's theory of constructive interpretation as well as Raz's theory of detached normative statements and reasoning from a point of view. After arguing that constructive interpretation can be undertaken from a point of view other than that of the interpreter, I go on to argue for the following claims: (1) Constitutional interpretation and review can be undertaken from the point of view of the democratic community and its constitutional morality; (2) This process can be undertaken by a judge without the deliberate intrusion of her own personal moral convictions; (3) When undertaken from this point of view, constitutional interpretation and review can be rendered consistent with democracy; and (4) This is so even when these activities require a good deal of substantive moral reasoning and argument on the part of judges.
\end{abstract}

\title{
Keywords:
}

Constitutional Interpretation, Judicial Review, Community's Constitutional Morality, Moral Reasoning, Political Morality, Democratic Legitimacy. 
Este libro forma parte del acervo de la Biblioteca Jurídica Virtual del Instituto de Investigaciones Jurídicas de la UNAM

CONSTITUTIONAL RIGHTS AND DETACHED CONSTRUCTIVE INTERPRETATION

Summary: I. Introduction. II. The Moral Reading. III. The Democratic Challenge. IV. CCM and the Democratic Challenge. V. Constructive Interpretation From a Point of View. VI. Objection 1: Application Versus Interpretation. VII. Objection 2: The circumstances of Judging. VIII. Conclusion. IX. Bibliography.

\section{INTRODUCTION}

Among the many individuals to whom I owe academic debts of gratitude three individuals stand out. First and foremost is my doctoral supervisor, H.L.A. Hart, from whom I continue to look for inspiration and insight. But just behind Hart stand two of his most famous and influential students: Joseph Raz and Ronald Dworkin, whose thoughts have also shaped my thinking on a number of jurisprudential topics. In this paper I intend to draw on Raz and Dworkin once again, this time in the service of developing a justification of judicial review under constitutional bills or constitutionals of rights. ${ }^{1}$ The view I sketch either represents a variation on the one Dworkin advances, or is in actual fact the view that Dworkin really meant to embrace. ${ }^{2}$ It turns on the idea that, in pursuing what Dworkin calls "constructive interpretation" of constitutional rights, judges need not aim to put the objects of their interpretations in their best moral light, as viewed from the perspective of the judges' own,

1 For reasons of convenience, I will henceforth refer to this practice as "constitutional review." I will also refer to the rights recognized in constitutional bills and charters of rights as "constitutional rights."

2 Whether I have correctly captured Dworkin's theory or have instead introduced a significant modification to it, is a question I will not address. My aim is to draw on Dworkin to address questions concerning the nature and justification of constitutional review, not to engage in an exercise of Dworkinian exegesis. 
Este libro forma parte del acervo de la Biblioteca Jurídica Virtual del Instituto de Investigaciones Jurídicas de la UNAM www.juridicas.unam.mx

WIL WALUCHOW

first-order moral judgments. ${ }^{3}$ Rather, following Raz, we can say that judges both can and characteristically do attempt to do so from the perspective of the democratic community and its first-order moral judgments. If this truly is possible, then we have at our disposal a promising way of addressing at least one major objection that has been leveled against Dworkin's moral reading and the practice of constitutional review it purports to justify - that it is inherently undemocratic. On Dworkin's moral reading, judges (or at the very least American judges) are authorized to strike down the considered legislative choices of democratically accountable legislators whenever they believe that the product of those choices runs afoul of the correctly interpreted rights of political morality expressed in the constitution. If we assume, as we surely must, that members of congress or parliament invariably believe that their legislative efforts are consistent with the constitution, properly interpreted, ${ }^{4}$ we seem led to the following conclusion: judges inevitably end up substituting their own moral judgments and constructive interpretations of constitutional rights for the considered judgments and constructive interpretations of democratically accountable legislators. And whatever might be said in favour of such a system of judicial intervention, one thing seems clear: its democratic legitimacy is far from obvious. But if my Razian take on the moral reading is correct, we may have a way round the democratic objection. And fur-

3 By the phrase first-order moral judgment, I will mean a judgment about what is morally best, required or valuable that is unencumbered by the judges' adjudicatory duty to accommodate constitutional history and the moral views of the democratic community that are expressed or embedded in them. In other words, it is a judgment about what "object" would ideally be best - not a judgment that attempts to make an existing, no doubt imperfect, object the best that it can be from the perspective of the community whose practices create and sustain it.

4 At the very least, we should assume that legislators do not actually believe that their legislation runs afoul of the constitution. We also seem safe in assuming that, if asked about the matter, they would claim constitutional compatibility. In short, barring highly unusual circumstances, no legislator deliberately sets out to violate the constitution. 
thermore, we may have a plausible theory of constitutional review and the interpretive acts that routinely surround its implementation. Or so I shall argue.

\section{The Moral ReAding}

Dworkin's moral reading of constitutions is an offshoot of his more general theory of interpretation, of which legal and constitutional interpretation are species. In Dworkin's view, the law of a community includes more than the explicit rules and decisions authoritatively adopted in accordance with accepted procedures and practices. That is, it includes much more than is (according to Dworkin) credited by positivism's so-called model of rules. ${ }^{5}$ It does, of course, include many such rules and decisions, and these can be found, paradigmatically, in statute books, judicial decisions and written constitutions. All these Dworkin is prepared to call the "settled law."6 But the settled law in no way exhausts the full law according to Dworkin. More importantly, for our purposes, it in no way exhausts, within the realm of constitutional practice, that part of law we call the constitution. In Dworkin's view, a constitution includes the principles of political morality that provide the best explanation and moral justification - i.e., the best constructive interpretation - of whatever written instruments in which its requirements are explicitly expressed, together with the institutional history of their interpretation by authoritative interpreters, most notably appeal courts. Hence, constitutional interpretation almost always invokes a normative theory of political morality. One concerned to interpret the limits upon government power and authority imposed by a constitution must develop an interpretive theory which provides what we might

5 See Chapter 2 of Taking Rights Seriously, "The Model of Rules 1."

6 Ronald Dworkin, Taking Rights Seriously (Harvard University Press 1978) 67-68, 79, 283, and 340. 
call the positive constitution and its interpretive history with their morally best explanation and justification. ${ }^{7}$

The development of an interpretive constitutional theory, Dworkin acknowledges, is an extremely difficult task, and people of good faith and integrity will both inevitably and reasonably disagree about which competing theory is best. There is no mechanical, morally neutral test to apply, only the competing interpretations of those whose task it is to interpret. This does not mean, however, that attempting to evaluate theories is impossible or foolish. Nor does it mean that there really is no such thing as a uniquely correct theory that embodies the true meaning of the constitution. In other words, the presence of disagreement, controversy and uncertainty surrounding the efforts of constitutional interpreters, does not entail that there are no right answers to the questions posed in any given constitutional case. Nor does it entail the absence of a uniquely correct theory of the constitution that determines what those answers are and hence what the positive constitution, properly interpreted, actually requires. The presence of such factors entails only that interpreters must, as they must do in all interpretive enterprises, including the arts, science, and the law more broadly, exercise judgment in fashioning their interpretive theories. Dworkin goes so far as to suggest that in a mature legal system there almost always will be a best constitutional theory, and judges (and legislators) can sensibly be charged with the duty to try their best to discern and im-

7 In what follows, the phrase 'positive constitution' should be taken to mean a formally adopted, written instrument like the Canadian Constitution Act, 1982, The Basic Law For the Federal Republic of Germany, or The Political Constitution of the United Mexican States. The word 'constitution' should, on the other hand, be taken to mean the positive constitution and its interpretive history, together with whatever principles provide that written instrument and that history with their best explanation and moral justification. 
plement its requirements in making their authoritative decisions. 8

There are, for our purposes, three important implications of Dworkin's moral reading of constitutional interpretation. First, factors like original meanings or the original intentions of a positive constitution's authors are seldom, if ever, dispositive of constitutional meaning. At best these historical factors set the stage for the ongoing interpretive debates of political morality which constitutional cases both licence and require.

Second, constitutional cases require the kind of fully normative decision-making which is, on competing, orthodox forms of originalism, properly undertaken only by those whose role it is to fix the constitutional limits contained within the positive constitution - i.e., its original authors or framers. ${ }^{9}$ The kind of morally and politically neutral process of constitutional interpretation envisioned by orthodox originalists is neither possible nor attractive on Dworkin's theory. And this is because the positive constitution is not a finished product, handed down in a form fixed till such time as its amending formula is invoked successfully or a revolution occurs. Rather it is a work in progress requiring continual revisiting and reworking as our constructive interpretations of its requirements and limits are refined and

8 Dworkin Taking Rights Seriously (n 7) chapter 13, most notably 286-90. It must be noted that Dworkin is concerned, in these pages, with right answers to most legal cases, not specifically those that turn on how best to interpret a positive constitution. But clearly Dworkin would say the same about the latter as he does about the former.

9 I say "orthodox forms of Originalism" so as to distinguish forms of that theory that functioned as Dworkin's main target from those that are closer to the moral reading. For an orthodox version of Originalism, see Antonin Scalia A Matter of Interpretation: Federal Courts and the Law (Princeton University Press, 1998); and Larry Alexander "Simple-Minded Originalism," The Challenge of Originalism: Essays in Constitutional Theory, G Huscroft \& BW Miller, eds (Cambridge University Press 2011); For a less orthodox version, see Jack's Balkin's Living Originalism (Harvard University Press 2011). 


\section{WIL WALUCHOW}

(it is hoped) improved over time. It is, in short, a living entity whose content is shaped by the interpretive decisions of numerous "authors." 10

A third, related implication of Dworkin's moral reading of constitutional interpretation is that judges are not mere agents whose fiduciary role is simply to carry out the decisions of political morality already made by the democratically authorized original authors (or amenders) of the constitution. On the contrary, they are partners with those authors in an ongoing, creative political project, one which requires participants, both then and now, to engage in the kind of first-order, moral/political decision-making that, on more orthodox originalist views, legitimately takes place only when the positive constitution is first adopted (and/or amended formally). Constitutional meaning is, on Dworkin's theory, continually in need of constructive interpretation and is, as a result, essentially contestable, ad infinitum. If there is a uniquely correct theory or interpretation it is one that must be indexed to time. That is, the correct interpretation at time $t_{1}$ may not be the correct interpretation at later time, $\mathrm{t}_{2}$.

A fourth implication of Dworkin's moral reading is one already touched upon but which deserves further emphasis: constitutional meaning is very, very difficult to determine and it is inevitably the subject of ongoing dispute and controversy. Indeed, the confident identification of constitutional meaning at any given time may well require the services of a constructive interpreter of enormous powers of moral, political and legal reasoning. It may, in other words, require the services of Dworkin's ideal judge Hercules. But of course Hercules is a product of Dworkin's imagination,

10 In explaining this feature of legal/constitutional interpretation, Dworkin draws on an analogy with the chain novel. This is one that is developed over time and through the efforts of multiple authors, each working to develop her own chapter both within the spirit of earlier ones and in anticipation of chapters yet to be written. See Ronald Dworkin Law's Empire (Harvard University Press 1988) 228-32. 
and so the project of interpreting the contestable terms of a constitution is, in reality, subject to countless disputes and uncertainties. It requires that each interpreter do her best to emulate Hercules' interpretive efforts. That is, she must endeavour to develop and implement her own best, undoubtedly imperfect interpretation of the limits placed upon government by her positive constitution and its interpretive history. Those limits are never fixed and she can never know, at any given point in time or with anything approaching absolute certainty, what they actually are. But this is what is demanded of her if Dworkin has accurately captured the nature and demands of constitutional interpretation.

\section{The Democratic Challenge ${ }^{11}$}

That it requires of judges the kind of enormously difficult, morally charged interpretive reasoning just described is an aspect of Dworkin's moral reading that many critics find deeply troubling. Not only does it mischaracterize what it is to interpret a written instrument, they say. ${ }^{12}$ It places in the hands of judicial interpreters far too much political power. Were Dworkin's moral reading applied to constitutional practices such as one finds in Mexico, the United States and Canada, the result would be, the critics contend, flagrantly undemocratic. The principal reason is that each of these jurisdictions embraces some version of constitutional review, a practice authorizing appointed judges to strike down or otherwise interfere with legislative actions properly undertaken by duly elected, democratically accountable legislators. ${ }^{13}$ Somewhat paradoxically, it is pre-

11 Some of the material in this section derives from my "Judicial Review” (2007) 2/2 Philosophy Compass 258-266.

12 See, e.g., Andrei Marmor, Interpretation and Legal Theory, (revised 2nd Edition, Oxford University Press 2005), especially chapter 3.

13 Constitutional review is sometimes addressed to executive action (or inaction) as well, but our focus here will be the review of legislation. For a 
cisely because judges are not electorally accountable that defenders of constitutional review are often prepared to invest them with the power to interfere with legislative efforts. Modern democracy is not to be identified with simple majority rule. Rather, it is a complex, multi-dimensional system of government under which everyone is treated as free and equal by all parties involved in the project of democratic self-government. ${ }^{14}$ Treating everyone as free and equal requires that all government parties respect a very basic set of individual (and possibly group) rights that go hand in hand with democratic membership. It also requires that each individual be accorded an equal say in the creation of law and in the direction of public policy. ${ }^{15}$ To be sure, this does usually require respecting majority will, something normally achieved through the use of majority voting procedures among elected, democratically accountable representatives whose primary responsibility is to create law and direct public policy in accordance with majority will and sentiment. But somewhat paradoxically, democracy occasionally requires the exact opposite. Majorities, perhaps unwittingly or in times of national stress or panic, periodically move to deny vulnerable individuals and groups the equal say and respect that democracy demands. Legislatures, elected bodies designed to be maximally responsive to majority will and sentiment, are not necessarily well positioned to make the hard choices sometimes re-

case where Constitutional review was directed at executive inaction, see Canada (Prime Minister) v. Khadr, 2010 SCC 3, [2010] 1 S.C.R. 44.

14 Dworkin refers to this position as the constitutional conception of democracy. See Ronald Dworkin Freedom's Law: The Moral Reading of the American Constitution (Harvard Univerity Press 1997) 17. For a defence of judicial review premised on a very robust constitutional conception of democracy, see Samuel Freeman, "Constitutional Democracy and the Legitimacy of Judicial Review," (1990-1991) 9 Law and Philosophy 327.

15 John Hart Ely has put forward the most influential defence of the view that judicial review is sometimes required to ensure adherence to legitimate democratic processes. See John Hart Ely Democracy and Distrust (Harvard University Press 1980). 
quired to protect individuals and minorities against the heavy hand of majority rule. Constitutions and constitutional review are thus heralded as useful or essential vehicles for protecting us from what Tocqueville famously termed the tyranny of the majority. ${ }^{16}$ They are viewed as embodying the rational pre-commitment of the community to protect these fundamental rights, rights essential to enlightened democratic rule and the free and equal exercise of individual autonomy. ${ }^{17}$

It is at this stage, of course, that the critics will pounce. Protecting our most basic rights through a process of constitutional review sounds like a wonderful idea, they will say. Who, after all, could object to rights protection? But now consider what this means in a world of deep moral and political disagreement, where interpreters are of limited ability and insight, and judges cannot even agree among themselves, let along with others within the wider democratic community, about the correct way to interpret any given constitutional right. Consider not what it would be like to have Hercules protecting your rights but instead the hard cold reality of having less-than-ideal judges with their less-than-ideal interpretive abilities attempting to do the same. Do we really want these people interfering with the considered judgments of our duly elected and accountable legislators? Yet this is the inevitable result, the critics con-

16 Alexis de Tocqueville, Democracy in America (Penguin Classics 1835), "Chapter XVI: Causes which Mitigate the Tyranny of the Majority in the United States."

17 For a full scale defense of this view, see Dworkin (n 7); Ronald Dworkin, A Matter of Principle (Cambridge University Press 1985); Dworkin (n 15); and A Bill of Rights for Britain (Ann Arbor, MI: University of Michigan Press, 1990. See also John Rawls, A Theory of Justice (Harvard University Press 1971) and Political Liberalism (Columbia University Press 1996); Samuel Freeman, 'Constitutional Democracy and the Legitimacy of Judicial Review' (1990-1991) 9 Springer 327, 320; and Wil Waluchow, A Common Law Theory of Judicial Review: The Living Tree (Cambridge University Press 2007); and Wil Waluchow "Democracy and the Living Tree Constitution,” (2011) 59 Drake Law Review 1001. 
WIL WALUCHOW

tend, if we follow Dworkin in embracing the moral reading. We end up violating the fundamental principles of democracy. Henceforth, we will refer to this serious difficulty as the democratic challenge.

\section{CCM AND The Democratic Challenge}

In previous work, I have tried my best to answer the democratic challenge by defending a theory of constitutional review under which the principal role of judges is not to draw on her own first-order convictions in regard to the issues of political morality that arise in constitutional cases, but to hold the community to its own fundamental moral commitments. These commitments are expressed in what I call the community's constitutional morality (CCM). $\mathrm{CCM}$ is not the personal morality of any particular person or institution, e.g. the Catholic Church, the Brazilian Democratic Movement Party, or a judge who helps decide a constitutional case. Nor is it the morality decreed by God, inherent in the fabric of the universe, or residing in Plato's world of forms. Rather, it is a kind of community-based, positive morality consisting of the fundamental moral norms and convictions to which the community has actually committed itself and which have acquired some kind of formal, entrenched constitutional recognition. It is the political morality actually endorsed in a community's constitutional practices. In many systems legal recognition of $\mathrm{CCM}$ norms includes (though it is not limited to) enshrinement in a bill or charter of rights and in the legislative history and jurisprudence that combine to flesh out the local, concrete understandings or Thomistic "determinations" of those principles for that particular community.

With this conception of constitutional morality in hand, I set out to defend constitutional review against the democratic challenge. Put simply, my thesis was that CCM, owing to its social origin, is a source of entrenched, fundamental moral norms upon which judges can draw in 
constitutional review without compromising democratic legitimacy. Constitutional review typically involves the task of ensuring that legislative acts do not infringe the more fundamental community commitments of CCM. If this is its nature, then democratic legitimacy need not be compromised. The judge may not be thwarting the democratic will but may, in effect, be helping to implement it or render it effective by enforcing its deepest moral commitments.

If only matters were this straightforward. But of course they are not. As some critics have pointed out, we seem reasonably to disagree not only about the demands of Platonic moral truth. Often we disagree vehemently about the demands of CCM as well.18 Of course, as Dworkin has repeatedly pointed out, the mere fact of disagreement in no way entails that there is no fact of the matter in such cases. ${ }^{19}$ But it is undeniable that such disagreement threatens to undermine the practical possibility of democratic legitimacy. How can the decision to apply a CCM norm in a particular way be reasonably viewed as reflective of the democratic will if there is so much disagreement and uncertainty about what the latter is and requires? Will judges not, in the end, be forced to choose from among the possibly large number of different interpretations on offer in such hard constitutional cases? And will they not end up having to ground their choice in what they, personally,

18 See, e.g., Bradley Miller, "Review Essay: A Common Law Theory of Judicial Review" (2007) 52 American Journal of Jurisprudence 297-312; N. Struchiner and F. Shecaira, "Trying to Fix Roots in Quicksand: Some Difficulties With Waluchow's Conception on the True Community Morality” (2009) 3 Problema Anuario de Filosofia y Teoría del Derecho,; Imer. B. Flores, "The Living Tree Constitutionalism: Fixity and Flexibility," Ibid.; Natalie Stoljar, "Waluchow on Moral Opinions and Moral Commitments," Ibid.; and Larry Alexander, "Waluchow's Living Tree Constitutionalism," (2010) 29 Law \& Philosophy 93.

19 This theme appeared and played a prominent role throughout Dworkin's career, up to and including some of his most recent work. See, e.g., Ronald Dworkin Justice For Hedgehogs (Harvard University Press 2011), passim, but especially Chapter 5 . 
think is the morally best option? What else could they do in such circumstances, short of simply declining to make a decision at all? Yet if this is so, do we not end up right back where we started: with the looming threat of the democratic challenge and the possibility that judges will be forced to rely on their own moral views. They may, in other words, be forced to rely on something like Dworkinian constructive interpretation where the aim is (supposedly) not to retrieve and articulate a reflective account of the community's prior constitutional commitments, but to render a sound judgment about which interpretation will put the community's constitutional practices in their best moral light. That is, we will be forced to rely on the judges' own first-order moral judgments.

But is this so? Must judges resort to first-order moral judgments when they engage in constructive interpretation? I'm not so sure. It is here, I suggest, that we might draw on a potentially important distinction: between

(a) putting an object of interpretation in its best moral light, as viewed from the perspective of a judge's own, first-order moral judgments; and

(b) doing so from the perspective of the democratic community and its first-order moral judgments.

In other words, even when interpreting CCM norms eventually involves an attempt to put those norms in their best moral light, there is no reason to think this must be done from the interpreter's own personal perspective. Drawing on Raz's theory of detached normative statements and reasoning from a point of view, I shall now argue for the following claims: (1) Constitutional interpretation and review can be undertaken from the point of view of the democratic community and its CCM commitments; (2) This process can be undertaken by a judge without the intrusion of her own, first-order moral convictions; (3) When undertaken from this point of view, constitutional interpretation and review 
are consistent with democracy; and (4) This is so even when these activities require a good deal of substantive moral reasoning and argument on the part of the judge.

\section{CONSTRUCTIVE InTERPRETATION From A POINT OF VieW}

Joseph Raz observes that there are at least three points of view from which one can approach the expression of a normative statement. First, a speaker can utter a normative statement which personally commits her to the view expressed. When Katharina says 'Kara did the right thing in keeping her promise to Maggie' she commits herself to the claim that Kara's action was, in fact, morally correct. ${ }^{20}$ When I, being confronted with a valid law of a legal system to which I am subject and which I fully support, say 'It would be wrong not to pay my taxes', I commit myself to the normative view I express. My statement is an internal statement uttered from what Hart famously called "the internal point of view." 21 A second point of view described by Hart is of course "the external point of view." 22 This is where I do not myself express or assert a normative point of view but rather describe the point of view of other people, perhaps by describing their beliefs, attitudes and actions regarding some normative situation. When I say that the British not only habitually queue up while awaiting public transit, but believe that this is the right thing to do and are prepared to criticize anyone who deviates from that pattern of behaviour, I describe their normative behaviour, beliefs and attitudes - and I do so from the external point of view. I describe what Hart called the observance of a "social rule"

20 Under normal circumstances we can assume that the statement is sincere. But even when it is not, the commitment is nevertheless expressed (if not endorsed).

21 Herbert Hart, The Concept of Law (3rd ed, Oxford University Press 2012) 89-91.

22 Ibid. 
accepted by them from the internal point of view. But I do so in a way that in no way commits me to the normative view expressed in observance and endorsement, by them, of that rule. Analogously, if I say that, under South African apartheid law, it was wrong for white people to have sexual relations with black people, I describe the state of law in 1920s South Africa. ${ }^{23}$ But quite obviously I don't commit myself in any way to the normative view described.

In addition to these two points of view, there is, according to Raz, a third alternative with its corresponding type of statement: the detached point of view and the detached normative statements expressed from that perspective. ${ }^{24}$ Focusing now on law, Raz claims that "A detached legal statement is a statement of law, of what legal rights or duties people have, not a statement about people's beliefs, attitudes, or actions, not even about their beliefs, attitudes, or actions about the law." 25 In other words, the statement cannot be reduced to an external statement of the form: ' $\mathrm{S}$ believes that he ought to do x' or 'The legal officials of legal system y have enacted law $\mathrm{L}$ requiring $\mathrm{x}$, and will therefore hold $\mathrm{S}$ accountable should he fail to do x.' But neither does the statement carry the full normative force that a legal statement from the internal point of view usually does. This is because it does not commit the speaker to acceptance of the normative view it expresses. ${ }^{26}$ A detached legal statement is like an internal statement in that it does use the law as a standard with

23 The Immorality Act, 1927. Sexual relations between blacks and whites remained illegal in South Africa till 1985 when the Parliament of South Africa introduced The Immorality and Prohibition of Mixed Marriages Amendment Act, 1985. See C. G. Van der Merwe, J. E. Du Plessis (eds) Introduction to the Law of South Africa (Kluwer Law International 2004).

24 Raz credits Kelsen with recognizing the importance of detached legal statements. They are, Raz suggests, "crucial to anyone holding his view on the meaning of 'validity' and rejecting natural law at the same time" Joseph Raz The Authority of Law: Essays on Law and Morality (Oxford University Press 1979), 155.

25 Ibid 153.

26 Ibid. 
which to evaluate and judge conduct. But it is different from any such statement in so far as it does not commit the speaker to the normative view expressed. It does not, at least necessarily, express his particular view of the matter. Raz observes that this third kind of statement is characteristically used by individuals, e.g. lawyers, who are neither concerned with describing social practices from the external point of view nor with applying the law to their own behaviour. Rather their aim is to inform others what they ought to do according to the law, and this information is conveyed from a point of view that is not necessarily that of the speaker. ${ }^{27}$ She needn't believe that this is the point of view people should actually take on the matter. As a result, the speaker who utters a detached legal statement merely needs to be able to construct the point of view so that the appropriate recommendation can be made. Most importantly, for our purposes, "[1]egal scholars - and this includes ordinary practising lawyers - can use normative language when describing the law and make legal statements without thereby endorsing the law's moral authority."28 Putting it another way, legal scholars - and this includes ordinary practising judges - can make legal statements without thereby expressing first-order moral judgments.

So detached legal statements seem clearly possible. ${ }^{29} \mathrm{But}$ the possibility of uttering a detached statement is in no way

27 Ibid 155. Indeed, it could be conveyed by an anarchist lawyer who in fact rejects the law completely. Normally, of course, lawyers endorse their legal system and its claims, and so their statements are internal ones. But Raz's point is that this is not necessary. It is possible to use legal standards to judge, evaluate and advise without actually endorsing the point of view they express. Think, here, of a progressive, liberal-minded lawyer in 1920s South Africa advising his client of his legal duties under The Immorality Act, 1927.

28 Ibid, 156.

29 For criticisms of Raz's theory of detached legal statements, see, Luis Duarte D' Almeida, 'Legal Statements and Normative Language', (2011) 30 Law and Philosophy 180. For further reflections on the theory, see 
WIL WALUCHOW

unique to law. It exists within any normative context, including morality and religion. Raz writes:

Imagine an orthodox, but relatively ill-informed Jew who asks the advice of his friend who is Catholic but an expert in Rabbinical law. 'What should I do?' he asks, clearly meaning what I do according to my religion, not yours. The friend tells him that he should do so and so. The point is that both know that this is not what the friend thinks that he really ought to do. The friend is simply stating how things are from the Jewish Orthodox point of view. 30

So once again, it seems possible to know and state what should be done from a point of view one does not necessarily endorse. Now if the possibility exists here, that is, from the point of view of the Jewish Orthodox community and its religious commitments, then there seems no reason to deny this possibility when we consider what should be done from the point of view of the democratic community and its fundamental constitutional commitments, i.e., when turning to the requirements of CCM. Here too it seems possible to render a detached judgment without necessarily endorsing the view expressed - i.e. without inserting one's own, first-order moral beliefs into the equation. Just as the Catholic friend can, in a detached manner, discern and express what should be done from the point of view of his Orthodox friend, a judge in a constitutional case should be able to discern and express, in an equally detached way, what should be done from the point of view of the democratic community and its CCM commitments. And if this is so, then we seem to have, once again, a potentially decisive answer to the democratic challenge. Judges who engage the process of constructive interpretation of constitutional rights are not - at least necessarily - relying on their own, personal first-order moral judgments.

Kevin Toh, 'Raz on Detachment, Acceptance and Describability' (2007) 27 Oxford Journal of Legal Studies January 3, 403-427.

30 Raz, The Authority of Law (n 25) 156. 


\section{OBJECTION 1: ApPLICATION VERSUs InTERPRETATION}

I anticipate, at this stage, a number of objections. Among them is the following: It is one thing to express a detached statement about the demands of norms whose meaning and application are indisputable (Raz's example). It is quite another to do so when all one has to offer is a highly disputable judgment about something as elusive and contestable as CCM norms. An unstated though crucial feature of Raz's example is, presumably, that the identity and meaning of the norms drawn on are clear and obvious to anyone who is in the know. And so no judgment, moral or otherwise, is required in order to express a detached - or committed claim about what they demand. The Catholic friend simply has to apply the relevant norms, something anyone who had knowledge of them could quite easily do. But the same cannot be said when one turns to the norms of CCM and their role in the resolution of a dispute surrounding the meaning and application of a constitutional right. One cannot here offer a judgment from a detached point of view because one cannot simply identify and apply the relevant norm(s) in a way that calls for no first-order moral reasoning. In Raz's example, the advisor needn't engage in anything remotely like constructive interpretation because he needn't consider what puts the relevant norm(s) and the practices they help sustain in their best moral light. In other words, he doesn't have to construct the relevant norms before applying them. But in the constitutional cases in which CCM norms are said to figure, that is precisely what is required. The judge must attempt to put the relevant norms and the practices they help sustain in their best moral light - and she cannot do so without leaving her detached perspective behind and exercising first-order moral reasoning and judgment. The judge, in having to interpret constructively the very norms she is called on to ap- 
ply, will be forced to exercise the kind of moral reasoning that invites the democratic challenge. ${ }^{31}$

This objection, were it sound, would probably be enough to undermine my attempt to render constitutional review consistent with democracy. ${ }^{32}$ But is it sound? This is far from clear. Nor is it clear that Dworkin would have disagreed with me on this question. For consider one important respect in which constructive interpretation must, on Dworkin's own account of it, be undertaken from a decidedly detached point of view. As Dworkin has always insisted in answering critics who claim that his theory encourages judges to "play fast and loose with the law," constructive interpretations must always fit the materials to be interpreted to some highly significant degree. ${ }^{33}$ The historical materials that set the stage for constructive legal interpretation statutes, decisions, and so on - include elements the interpreter might very well wish were not there to constrain her interpretations. But they are there and they will invariably

31 A version of this argument is defended by Stephen Perry in a number of articles, most notably: Stephen Perry "Interpretation and Methodology in Legal Theory," Andrei Marmor ed. Law and Interpretation: Essays in Legal Philosophy (Oxford University Press 1995); and Stephen Perry "The Varieties of Legal Positivism" (1996) 9 Canadian Journal of Law \& Jurisprudence 361. In those papers, Perry addresses the interpretation of the concept of law, not the interpretation of moral concepts, principles and values that find their way into constitutionals or bills of rights. But the argument would be much the same - as would my response to it.

32 This is not to say, of course, that there might not be other avenues open to one who wishes to argue that constitutional review is consistent with democracy.

33 John Mackie was one of the first to level this charge against Dworkin. "...I am tempted to speak of Professor Dworkin playing fast and loose with the law. The alleged determinacy of the law in hard cases is a myth, and the practical effect of the acceptance of this myth would be to give... a larger scope for what is in reality judicial legislation...[I]it would shift the boundary between the settled and the unsettled law, it would make what on another view would be easy cases into hard ones....[I]t would encourage judges...to rely upon their necessarily subjective views about a supposedly objective morality." John Mackie, "The Third Theory of Law" (1977) 7 Philosophy and Public Affairs 15-16. 
restrict her interpretive efforts in highly significant ways. And importantly, for our purposes here, they will serve to obstruct any attempt, by the interpreter, to impose her own moral views.

[T]he brute facts of legal history will...limit the role any judge's personal convictions of justice can play in his decisions. Different judges will set this threshold [of fit] differently. But anyone who accepts law as integrity must accept that the actual political history of his community will sometimes check his other political convictions in his overall interpretive judgment. ${ }^{34}$

An instructive way of viewing Dworkin's fit condition, I suggest, is to see it as requiring that constructive interpretation be undertaken, not from the point of view of the interpreter and her own first-order moral beliefs, but from the point of view of a particular community with its own distinctive history of decisions and commitments. It must be undertaken from that point of view, just as the advice of the Catholic advisor must be offered from the point of view of the Orthodox Jewish community and its own particular history of decisions, rules, doctrines and commitments. A committed Marxist judge could no more offer a plausible constructive interpretation of American property law, according to which private property amounts to theft, than the Catholic friend could sincerely advise his friend that he need not observe the Sabbath. This could not be a sensible constructive interpretation of American property law but could be nothing more than an expression of the judge's own, personal first-order moral views about how property should, in an ideal world, be distributed. One could, I suppose, refer to this Marxist take as an "interpretation," one that potentially puts American property law in its ideally best moral light. But it could not possibly count as a constructive interpretation because it does not fit the relevant

34 Dworkin Law's Empire (n 11) 255. 
institutional history. Putting it in terms relevant to our current discussion, it is not made from the perspective of the American community and its history of moral commitments with respect to the proper distribution of property. It does not construct that history so much as suggest how it might, in an ideal world, have been better.

Fair enough, it might be countered. But this is still not enough to rescue constructive interpretation from the grip of the democratic challenge. And this is because, as Dworkin rightly acknowledges, more often than not there will be no uniquely correct constructive interpretation that adequately fits the materials to be interpreted. To be sure, a Marxist interpretation of American property law could not reasonably be thought to fit the relevant object of interpretation and is therefore be excluded as a sensible candidate. But there will inevitably be other plausible interpretations and each of these will surpass the "threshold test" of fit. ${ }^{35}$ For instance, certain rival libertarian interpretations, as well as others favoured by devotees of law and economics, are likely to survive the test and remain as plausible constructive accounts of the American community's commitments with respect to property. Hence it will not be possible in these cases to identify a unique point of view from which detached constructive interpretation can take place. On the contrary, there will only be a variety of such perspectives and their corresponding interpretations. And choosing from among these will inevitably demand of the judge the very kind of first-order moral reasoning and judgment that invites the democratic challenge. She will be forced to choose, from among the available points of view, the one she thinks is morally best, ideally speaking. And so the democratic challenge again rears its ugly head. The process of con-

35 Dworkin (n 7) Taking Rights Seriously, 342. In terms used in early statements of his interpretive theory of law, Dworkin writes: "[N]o principle can count as a justification of institutional history unless it provides a certain threshold adequacy of fit, though amongst those principles that meet this test of adequacy the morally soundest must be preferred." 
structive interpretation will inevitably force "judges...to rely upon their necessarily subjective views about a supposedly objective morality."36

Once again, however, we need to question the validity of the inference being drawn here. It is beyond contention that the interpreter may be forced to choose from among rival interpretations that more or less fit the historical record, a step that will inevitably require a full-blown attempt to put that record in its best moral light. Let us accept all this. In other words, let us accept that constructive interpretation requires, in this instance, a good faith attempt by the judge to place the object of her interpretation in its best moral light. None of this entails that the light shed must be a product of the judge's own first-order moral commitments. On the contrary, it can still be a light shed by the wider set of moral values, principles and settled doctrines revealed in a reflective account of the community's prior constitutional decisions and commitments - i.e. its CCM. To be sure, these moral values, principles and doctrines are not always easy to uncover and their precise identity and import is almost always subject to reasonable, ongoing disagreement and argument among good faith interpreters. But as Dworkin has always insisted, this fact is neither here nor there. Reasonable disagreement and argument are hallmarks of political morality in all its forms and dimensions, and do not preclude the possibility of right answers. Nor do they preclude our sensibly requiring interpreters to strive continually to uncover those answers and render their interpretive decisions in light of them. To be sure, personal judgment is called for here - and it's a form of judgment that can quite sensibly be viewed as moral in nature. But it is not the kind of first-order moral judgment that renders us vulnerable to the democratic challenge. An interpretive decision undertaken from this point of view is no more a reflection of the interpreter's first-order moral convictions and preferences than is our Catholic friend's advice to his Or-

36 Mackie (n 34) The Third Theory of the Law 16. 
WIL WALUCHOW

thodox friend. Furthermore, it need not be viewed as an alien force that threatens the very foundations of our democracies. Insofar as, and to the extent that, the interpretation is based on a good faith attempt to put its object in its best light, as judged from the moral perspective of the democratic community and its fundamental moral commitments, it is one which all reasonable citizens can and should accept as an expression of their sovereign democratic will.

\section{OBJECTION 2: The CIRCUMSTANCES OF JUDGing}

A key premise in my Dworkin/Raz-inspired defence of constitutional review is that constructive interpretations can be generated from a detached point of view. Just as one can discern and apply the law of Apartheid South Africa without endorsing the norms applied, one can discern, interpret and apply the requirements of CCM without endorsing the point of view it represents. It might be objected, however, that this defence fails because it misconstrues what it is to be a judge. In other words, the defence seriously misrepresents the perspective of judges when they decide cases, especially those in which constructive interpretation is required. In one of his early articles, Raz observes that judges do not, at least typically, take a detached point of view towards their legal systems and their laws.

Judges, if anyone, take the law as it claims it should be taken. They more than anyone acknowledge the law at its own estimation. To understand legal statements we should interpret them as meant by those who take them and accept them at face value, those who acknowledge the law in the way it claims a right to be acknowledged. The decisive argument concerning the meaning of statements of legal duties is that the law claims for itself moral force. ${ }^{37}$

37 Joseph Raz, "Hart on Moral Rights and Legal Duties" (1984) 4 Oxford Journal of Legal Studies 131. 
If Raz is right that judges accept the moral force the law claims for itself, then their legal judgments (and the statements they make in asserting them) will be anything but detached. 38 On the contrary, they must be fully committed, first-order moral judgments and statements about what really ought, morally to be done. ${ }^{39}$ And so the kind of detached constructive interpretation that would arguably be invulnerable to the threat posed by the democratic challenge is unavailable as a ground for defending constitutional review.

But is this so? Once again, I fail to see why. There is little doubt that judges in modern constitutional democracies, such as one finds in Canada, Germany, the UK and Mexico, are typically committed to the moral authority of their legal systems. They deem these systems morally worthy of support and view the roles they play within them as endowed with morally legitimacy. But two points need to be stressed here. First, that judges typically take this view is clearly not necessary any more than it is necessary when one turns to lawyers. That is, the kind of moral commitment that judges typically display is not essential to assuming the role of judge. As Hart observed long ago, there are many reasons why people become judges and agree to abide by the basic ground rules of the system, and only some of these have anything to do with morality. 40 Secondly, and more importantly for our purposes, it is not true that a judge who fully endorses and accepts the moral authority the law claims for itself, and who recognizes and endorses a moral obligation to discern, interpret and apply its requirements in deciding cases, is necessarily committed to endorsing the point of

38 On this point, Dworkin is no doubt in agreement with Raz. According to Dworkin, legal judgments purport to justify the use of coercive measures against citizens. And so a judge who offers a constructive interpretation of the relevant law offers one which, in her view, really would help to justify morally the coercion her judgment would occasion.

39 Once again, for Dworkin they must morally justify the employment of coercion against citizens.

40 See Hart The Concept of Law (n 22) 202-3. 


\section{WIL WALUCHOW}

view expressed by the law on any particular issue of moral significance. Judges often disagree morally with the individual laws they consider themselves bound, legally, morally and prudentially, to apply. Sometimes they express regret that their judicial duty compels them to apply a law they find deeply problematic on moral grounds. On rare occasions judges may even go so far as to refuse to apply a law with which they disagree morally, thus resorting to what Jeff Brand-Ballard calls "lawless judging." 41 None of this shows that detached judgment is not possible when judges engage in constructive interpretation of constitutional rights. And the reason should by now be clear.

Even though most judges are fully committed to the moral authority of their legal systems and the role they play within it, most also view their adjudicative role as bringing with it a first-order moral commitment to apply the law as it is, not as it ought to be. It follows from this that a judge who accepts and endorses the moral authority of her legal system and its constituent constitutional practices may feel compelled to construct and apply an interpretation of that practice that she personally finds morally problematic. That is, she may feel compelled to adopt an interpretation that accords with CCM commitments but that fails, from her own personal moral perspective, to put the relevant law in its ideally best moral light.42 From that personal perspective, it's not the best it could be. But it is, nevertheless, an interpretation that puts that law in its best moral light, as judged from the perspective of the democratic community and

41 For an excellent discussion of whether judges are always under duty to apply the law in reasonably just legal systems, see Jeffrey Brand-Ballard, Limits of Legality: The Ethics of Lawless Judging (Oxford University Press 2010).

42 Think here of a judge fully committed to a theory steeped in the economic analysis of law. She might acknowledge that her theory and its resultant interpretation can be made to fit the historical record. She might, however, be compelled to admit that it would fail to put that record in its best moral light as judged from the moral perspective expressed and endorsed in that record. 
its own particular history of moral decisions and commitments. If (a) the judge endorses her legal system as morally worthy of acceptance and support; (b) accepts and endorses her moral obligation to decide according to its demands when engaged in the process of judging; and if (c) what that moral obligation demands is an interpretation constructed from the point of view of the legal system and its history of CCM commitments, then (d) she will consider herself morally bound (in a non-detached, i.e., fully committed way) to accept a constructive interpretation she would, in an ideal world, prefer to reject. And if she always acts on this understanding of her judicial moral obligation she will, I, suggest, do nothing that leaves her vulnerable to the criticism expressed by the democratic challenge.

\section{CONCLUSION}

In this paper I have defended constitutional review against the charge that it necessarily runs afoul of democratic principle. In so doing, I drew both on Dworkin's theory of constructive interpretation as well as Raz's theory of detached normative statements and reasoning from a point of view. After arguing that constructive interpretation, which necessarily aims to place its object in its best moral light, can be undertaken from a point of view other than that of the interpreter, I went on to argue for the following claims: (1) Constitutional interpretation and review can be undertaken from the point of view of the democratic community and its CCM commitments; (2) This process can be undertaken by a judge without the deliberate intrusion of her own, first-order moral convictions; (3) When undertaken from this point of view, constitutional interpretation and review can be rendered consistent with democracy; and (4) This is so even when these activities require a good deal 
Este libro forma parte del acervo de la Biblioteca Jurídica Virtual del Instituto de Investigaciones Jurídicas de la UNAM

WIL WALUCHOW

of substantive moral reasoning and argument on the part of judges. ${ }^{43}$

\section{BIBLIOGRAPHY}

Alexander Larry, "Simple-Minded Originalism" The Challenge of Originalism: Essays in Constitutional Theory (G. Huscroft \& B.W. Miller, eds. Cambridge University Press 2011).

,Waluchow's Living Tree Constitutionalism" (2010) 29 Law \& Philosophy 93.

Balkin's Jack's, Living Originalism (Harvard University Press 2011).

Brand-Ballard Jeffrey, Limits of Legality: The Ethics of Lawless Judging (Oxford University Press 2010).

Duarte D' Almeida Luis, "Legal Statements and Normative Language" (2011) 30 Law and Philosophy 167.

Dworkin Ronald, Taking Rights Seriously (Harvard University Press 1978).

—, A Matter of Principle (Cambridge University Press 1985).

— Law's Empire (Harvard University Press 1988).

—, A Bill of Rights for Britain (Ann Arbor, MI: University of Michigan Press 1990).

- Freedom's Law: The Moral Reading of the American Constitution (Harvard Univerity Press 1997).

43 Earlier versions of this paper were presented at: The Instituto de Investigaciones Juridicas, The Autonomous University of Mexico, Mexico City, February 2014; Faculty of Law, Western University, London, Ontario, March 2014; and "The First International Conference on Constitutional Law and Political Philosophy," Universidade Federal de Minas Gerais, Bello Horizonte, Brazil, November 2014. I am grateful for useful feedback received on all these occasions. A special word of thanks to Katharina Stevens for very helpful discussion of some of the issues addressed in this paper. 
—, Justice For Hedgehogs (Harvard University Press 2011).

Freeman Samuel, "Constitutional Democracy and the Legitimacy of Judicial Review" (1990-1991) 9 Law and Philosophy 327.

Hart Ely John, Democracy and Distrust (Harvard University Press 1980).

Hart Herbert, The Concept of Law (3 $3^{\text {rd }}$ ed., Oxford University Press 2012).

Mackie John, "The Third Theory of Law" (1977) 7 Philosophy and Public Affairs 3.

Marmor Andrei, Interpretation and Legal Theory (2nd Ed, Oxford University Press 2005).

Miller Bradley, "Review Essay: A Common Law Theory of Judicial Review" (2007) 52 American Journal of Jurisprudence 297.

Perry Stephen, "Interpretation and Methodology in Legal Theory" Andrei Marmor ed. Law and Interpretation: Essays in Legal Philosophy (Oxford University Press 1995).

Rawls John, A Theory of Justice (Harvard University Press 1971).

_- Political Liberalism (Columbia University Press 1996).

Raz Joseph, The Authority of Law: Essays on Law and Morality (Oxford University Press 1979).

_- "Hart on Moral Rights and Legal Duties" (1984) 4 Oxford Journal of Legal Studies 131.

Scalia Antonin, A Matter of Interpretation: Federal Courts and the Law (Princeton University Press 1998).

Tocqueville, Alexis de, Democracy in America (Penguin Classics 1835). 
Toh Kevin, "Raz on Detachment, Acceptance and Describability" (2007) 27 Oxford Journal of Legal Studies January 403.

Van der Merwe, J E Du Plessis (eds) Introduction to the Law of South Africa (Kluwer Law International 2004).

Waluchow Wil, “Judicial Review” (2007) 2/2 Philosophy Compass 258.

- - A Common Law Theory of Judicial Review: The Living Tree (Cambridge University Press 2007).

_ , 'Democracy and the Living Tree Constitution” (2011) 59 Drake Law Review 1001.

\section{LEGISLATION}

Canada (Prime Minister) v. Khadr, 2010 SCC 3, [2010] 1 S.C.R. 44. 